\title{
Effect of Integrated Nutrient Management on Flowering Characters of Cocoa
}

\author{
P. Leela Janaki ${ }^{*}$, G. Ramanandam and K. Sasikala \\ Horticulture, East Godavari district, Andhra Pradesh, India \\ *Corresponding author
}

\begin{abstract}
A B S T R A C T
\end{abstract}
\section{Keywords}

Integrated nutrient management, Horticulture

\section{Article Info}

Accepted:

12 December 2017

Available Online:

10 January 2018
An experiment was conducted during 2016 and 2017 to investigate the impact of integrated nutrient management on flowering characters of cocoa at existing coconut gardens, Horticultural research station, Ambajipeta. The study was laid out in randomized block design with ten treatment replicated thrice. The study shown that, the highest flowers per tree (4833.85) was recorded in $\mathrm{T}_{2}(75 \% \mathrm{RDF}+25 \% \mathrm{RDN}$ through CCP+ $50 \mathrm{~g}$ Azospirillum $+50 \mathrm{~g}$ PSB) and lowest flowers per cushion (2019.50) was recorded in $\mathrm{T}_{10}$ (control). However, the trees treated with $75 \% \mathrm{RDF}+25 \% \mathrm{RDN}$ through composted coir pith+ 50g Azospirillum $+50 \mathrm{~g}$ PSB had recorded highest values of flower cushions per main stem and fan branches, flowers per each cushion in main stem and fan branches and pod setting percent (4.32). INM treatment with $75 \%$ $\mathrm{RDF}+25 \% \mathrm{RDN}$ through $\mathrm{CCP}+50 \mathrm{~g}$ Azospirillum $+50 \mathrm{~g}$ PSB recorded the maximum flowering characters.

\section{Introduction}

Cocoa (Theobroma cacao L.) the 'Food of Gods' is a tree originated from the neotropical rainforests of the Amazon basin and Guyana Plateau of South America belong to the family Malvaceae (Alverson et al., 1999 and Bayer et al., 1999). It is a diploid species with 20 chromosome in the somatic cells $(2 n=20)$. Cocoa is now grown in the tropical regions from $10^{\circ}$ to $20^{\circ}$ latitude North or South of the equator (Motamayor et al., 2002). One of the most important plantation crops consumed worldwide and around 40-50 million people depend on cocoa for their livelihood. Cultivation of cocoa is done primarily for the production of chocolate and various byproducts are used in cosmetics, confectioneries, perfumeries and pharmaceuticals. Considering the high yield potential in cocoa, nutrient application with due consideration on various crop growth stages viz., vegetative, flowering, pod set, pod development and maturity will help in realizing the potential yield (Krishnamoorthy and Rajamani, 2013). Flowering is cauliflorous and flowering cycle follows certain seasonal patterns. In Andhra Pradesh, it occurs from January to December with a peak in September to October. Flowering and fruit set are the most critical events occurring after establishment of a crop. Fertilization at 
proper time and proper dose will increase the pod yield. Flowering in cocoa is determined by multi various factors like genetic factor, environmental factors like temperature, light intensity, rainfall, age of the tree, plant growth hormones, availability of soil moisture and nutrients as reported by Thondaiman (2011). Hence, the present study was undertaken to evaluate the flowering characters and yield characters of cocoa using different INM treatments.

\section{Materials and Methods}

The experiment site was located at Horticultural Research Station, Ambajipeta, East Godavari District, Andhra Pradesh. The location falls under Agro-climatic zone-10, humid, East Coast Plain and Hills (KrishnaGodavari zone) with an average rainfall of 900 $\mathrm{mm}$, located at an altitude of $34 \mathrm{~m}$ above mean sea level. The geographical situation is $16.83^{0}$ $\mathrm{N}$ latitude and $81.5^{\circ} \mathrm{E}$ longitude. It experiences hot humid summer and mild winters. Fourteen year old cocoa trees were selected for the study. In coconut plantation of thirty year old with spacing of $8 \times 8 \mathrm{~m}$, the cocoa plants are intercropped with a spacing of $3 \times 3 \mathrm{~m}$. The study was laid out in randomized block design with ten treatments. The treatment details were $75 \%$ RDF $+25 \%$ RDN through composted coir pith $\left(\mathrm{T}_{1}\right), 75 \% \mathrm{RDF}+25 \%$ RDN through composted coir pith+ 50g Azospirillum $+50 \mathrm{~g}$ PSB $\left(\mathrm{T}_{2}\right), 50 \% \mathrm{RDF}+$ $50 \%$ RDN through composted coir pith $\left(\mathrm{T}_{3}\right)$, $50 \%$ RDF $+50 \%$ RDN through composted coir pith $+50 \mathrm{~g}$ Azospirillum $+50 \mathrm{~g}$ PSB $\left(\mathrm{T}_{4}\right)$, $75 \%$ RDF + 25\% RDN through FYM $\left(\mathrm{T}_{5}\right)$, $75 \%$ RDF + 25\% RDN through FYM + 50g Azospirillum $+50 \mathrm{~g}$ PSB $\left(\mathrm{T}_{6}\right), 50 \% \mathrm{RDF}+$ $50 \%$ RDN through $\mathrm{FYM}\left(\mathrm{T}_{7}\right), 50 \% \mathrm{RDF}+$ $50 \%$ RDN through FYM+ 50g Azospirillum + $50 \mathrm{~g}$ PSB $\left(\mathrm{T}_{8}\right), 100 \% \mathrm{RDF}\left(\mathrm{T}_{9}\right)$ and Control $\left(\mathrm{T}_{10}\right)$. The recommended dosage of $\mathrm{N}, \mathrm{P}$ and $\mathrm{K}$ for cocoa is 100:40:140 g/tree/year. In inorganic fertilizer treatments $(50 \%, 75 \%$ and
$100 \%$ recommended dose of fertilizers) nitrogen, phosphorus and potassium nutrients were applied in the form of urea, single super phosphate and muriate of potash respectively. Nitrogen, Phosphorus and Potash was applied in two equal split doses i.e., first split during August and second split in November. Farm yard manure was obtained by composting different crop residues along with animal dung and only fully decomposed manure was used. The composted coir pith was obtained by composting the coir pith obtained from coconut husk. Biofertilizers viz., Azospirillum and Phosphate solubilizing bacteria (PSB) were obtained from University Bio-fertilizer production unit (BFU) Horticultural Research Station, V.R. Gudem, West Godavari District of Andhra Pradesh. The Azospirillum and PSB @ $50 \mathrm{~g} /$ tree was inoculated with the respective organic manures thoroughly and incorporated in the soil after one month of first split of inorganic fertilizer application to the trees. Regular irrigations and other agronomic practices were adapted to all the treatments as per the recommendations of cocoa cultivation.

The observations on flowering characters were recorded as per standard procedures from July to December and analyzed statistically. The total number of flower cushions produced per main stem and fan branches throughout the tree was counted and number of flowers per each cushion was counted in main stem and fan branches. The old flowers were identified and excluded by the dried appearances of the stigmatic surface, change of the petal colour from creamy white to deep yellow was counted. The total number of flower cushions and number of flowers per each cushion were multiplied for main stem and fan branches, expressed in numbers. The total number of flowers per tree was calculated by using the formula, Total number of flowers per tree $=$ Number of flowers /main stem/tree + Number of flowers/fan branches/tree. The number of main branches at jorquette and number of fan 
branches arising from first jorquette were counted and expressed in numbers and the percentage pod setting was calculated by using the following formula.

Number of pods harvested + cherriles + Pod rot and rodent affected pods Pod set per cent $=$ $\times 100$

Total number of flowers per tree

The results of this study were analyzed and discussed in the paper.

\section{Results and Discussion}

The non-significant differences were observed among the treatments with respect to number of fruiting branches per tree. The highest fruiting branches (4.99) was recorded in $\mathrm{T}_{2}$ (75\% RDF + $25 \%$ RDN through CCP+ $50 \mathrm{~g}$ Azospirillum $+50 \mathrm{~g}$ PSB) and lowest number of fruiting branches per tree of 4.22 in $T_{10}$ (control) (Table 1). The flower cushions per main stem varied significantly among the different treatments. The highest flower cushions per main stem of 35.70 was recorded in $\mathrm{T}_{2}(75 \% \mathrm{RDF}+25 \% \mathrm{RDN}$ through CCP $)$ which was on par with $\mathrm{T}_{1}, \mathrm{~T}_{3}, \mathrm{~T}_{5}, \mathrm{~T}_{6}, \mathrm{~T}_{7}, \mathrm{~T}_{8}$, $\mathrm{T}_{9}$ of $32.60,31.31,31.72,33.00,34.45,33.01$, 33.35 respectively. While lowest flower cushions per main stem (24.89) was recorded in $\mathrm{T}_{10}$ (control). The flowers per each cushion in the main stem were recorded from July to December varied significantly among the different treatments. The total flowers per main stem per tree varied significantly among the different treatments. The highest flowers per main stem per tree (1256.35) was recorded in $\mathrm{T}_{2}(75 \% \mathrm{RDF}+25 \% \mathrm{RDN}$ through $\mathrm{CCP}+$ $50 \mathrm{~g}$ Azospirillum $+50 \mathrm{~g}$ PSB) and lowest flowers per main stem (600.52) in $T_{10}$ (control) (Table 2). The flower cushions per fan branch varied significantly among the different treatments. The highest flower cushions per fan branch of 194.01 was recorded in $\mathrm{T}_{2}(75 \% \mathrm{RDF}+25 \% \mathrm{RDN}$ through CCP) which was on par with $\mathrm{T}_{1}, \mathrm{~T}_{3}$, $\mathrm{T}_{4}, \mathrm{~T}_{5}, \mathrm{~T}_{6}, \mathrm{~T}_{7}, \mathrm{~T}_{9}$ of $157.30,176.10,168.50$, 174.29, $164.19, \quad 176.11$ and 158.58 respectively. While lowest flower cushions per fan branch (113.53) were recorded in $T_{10}$ (control). The flowers per each cushion in the fan branches were recorded from July to December varied significantly among the different treatments. The total flowers per fan branches in a tree varied significantly among the different treatments.

The highest flowers per fan branches per tree (3577.50) was recorded in $\mathrm{T}_{2}$ (75\% RDF + 25 $\%$ RDN through CCP+ $50 \mathrm{~g}$ Azospirillum $+50 \mathrm{~g}$ PSB) which was on par with $\mathrm{T}_{3}$ (2944.41) (50\% RDF + 50\% RDN through $\mathrm{CCP}), \mathrm{T}_{4}(3014.64)(50 \% \mathrm{RDF}+50 \% \mathrm{RDN}$ through CCP $+50 \mathrm{~g}$ Azospirillum $+50 \mathrm{~g}$ PSB), $\mathrm{T}_{5}$ (2860.09) (75\% RDF + $25 \% \mathrm{RDN}$ through FYM) and $\mathrm{T}_{7}(2842.45)(50 \% \mathrm{RDF}+$ $50 \%$ RDN through FYM). While the lowest flowers per fan branches (1418.97) in $\mathrm{T}_{10}$ (control) were recoded (Table 3). The data reveals that the effect of integrated nutrient management on total number of flowers per tree was significantly differed among different treatments. The highest flowers per tree (4833.85) was recorded in $\mathrm{T}_{2}(75 \% \mathrm{RDF}+25$ $\%$ RDN through $\mathrm{CCP}+50 \mathrm{~g}$ Azospirillum $+50 \mathrm{~g}$ PSB) and lowest flowers per cushion (2019.50) was recorded in $\mathrm{T}_{10}$ (control). The highest pod set percentage (4.32) was recorded with $\mathrm{T}_{2}(75 \% \mathrm{RDF}+25 \% \mathrm{RDN}$ through $\mathrm{CCP}+50 \mathrm{~g}$ Azospirillum $+50 \mathrm{~g}$ PSB) which was on par with $\mathrm{T}_{1}$ (4.07) $(75 \% \mathrm{RDF}+$ $25 \%$ RDN through CCP). While, lowest pod set percentage (1.86) was recorded in $\mathrm{T}_{10}$ (control) (Table 4).

The number of fruiting branches did not differ among the treatments, because the pruning and training measures taken up during early stages of growth might have contributed to the uniform architectures. The same results were also reported by Elain Aphsara et al., (2008). 
Table.1 Effect of different INM treatments on fruiting branches and flower cushions per main stem and fan branches of cocoa (Theobroma cacao L.)

\begin{tabular}{|c|c|c|c|}
\hline Treatments & $\begin{array}{l}\text { Number of } \\
\text { fruiting } \\
\text { branches/tree }\end{array}$ & $\begin{array}{c}\text { Number of flower } \\
\text { cushions/main stem } \\
\text { /tree }\end{array}$ & $\begin{array}{c}\text { Number of flower } \\
\text { cushions/fan branches } \\
\text { /tree }\end{array}$ \\
\hline $\mathrm{T}_{1}: 75 \% \mathrm{RDF}+25 \% \mathrm{RDN}$ through CCP & $4.88(2.42)$ & $32.60(5.79)$ & $157.30(12.55)$ \\
\hline $\mathrm{T}_{2}: 75 \% \mathrm{RDF}+25 \% \mathrm{RDN}$ through CCP + 50g Azospirillum + 50g PSB & $4.99(2.44)$ & $35.70(6.05)$ & $194.01(13.94)$ \\
\hline $\mathrm{T}_{3}: 50 \% \mathrm{RDF}+50 \% \mathrm{RDN}$ through CCP & $4.72(2.39)$ & $31.31(5.68)$ & $176.10(13.29)$ \\
\hline $\mathrm{T}_{4}: 50 \% \mathrm{RDF}+50 \%$ RDN through CCP + 50g Azospirillum + 50g PSB & $4.27(2.29)$ & $29.96(5.55)$ & $168.50(13.00)$ \\
\hline $\mathrm{T}_{5}: 75 \% \mathrm{RDF}+25 \% \mathrm{RDN}$ through FYM & $4.33(2.30)$ & $31.72(5.71)$ & $174.29(13.22)$ \\
\hline $\mathrm{T}_{6}: 75 \%$ RDF + $25 \%$ RDN through FYM + 50gAzospirillum + 50g PSB & $4.65(2.37)$ & $33.00(5.82)$ & $164.19(12.82)$ \\
\hline $\mathrm{T}_{7}: 50 \% \mathrm{RDF}+50 \% \mathrm{RDN}$ through FYM & $4.38(2.32)$ & $34.45(5.94)$ & $176.11(13.29)$ \\
\hline $\mathrm{T}_{8}: 50 \% \mathrm{RDF}+50 \%$ RDN through FYM + 50g Azospirillum + 50g PSB & $4.49(2.34)$ & $33.01(5.82)$ & $154.63(12.43)$ \\
\hline $\mathrm{T}_{9}: 100 \% \mathrm{RDF}$ & $4.33(2.30)$ & $33.35(5.85)$ & $158.58(12.60)$ \\
\hline $\mathrm{T}_{10}:$ Control & $4.22(2.28)$ & $24.89(5.08)$ & 113.53 (10.69) \\
\hline$\overline{S E ~} \mathbf{m} \pm$ & 0.04 & 0.15 & 0.49 \\
\hline $\mathrm{CD}(\mathrm{P}=\mathbf{0 . 0 5})$ & NS & 0.45 & 1.47 \\
\hline $\mathrm{CV}(\%)$ & 3.15 & 4.54 & 6.67 \\
\hline
\end{tabular}

RDF- Recommended dose of fertilizers

FYM- Farm yard manure

Figures in the parenthesis indicates square root transformed values
RDN-Recommended dose of nutrients

PSB-Phosphate solubilizing bacteria CCP-Composted coir pith

CC
CP-Composted coir pith 
Table.2 Effect of different INM treatments on flowers per cushion in main stem of cocoa (Theobroma cacao L.)

\begin{tabular}{|c|c|c|c|c|c|c|}
\hline \multirow[t]{2}{*}{ Treatments } & \multicolumn{6}{|c|}{ Number of flowers/cushion in the main stem } \\
\hline & July & August & September & October & November & December \\
\hline $\mathrm{T}_{1}$ & 2.83 (1.95) & $5.38(2.52)$ & $8.46(3.07)$ & $8.28(3.04)$ & $3.84(2.19)$ & $0.97(1.40)$ \\
\hline$T_{2}$ & $3.97(2.22)$ & $4.70(2.38)$ & $10.93(3.45)$ & $8.99(3.16)$ & $4.46(2.33)$ & 2.03 (1.74) \\
\hline $\mathbf{T}_{3}$ & $2.60(1.89)$ & $5.35(2.50)$ & $9.52(3.24)$ & $8.29(3.04)$ & $3.49(2.11)$ & $0.65(1.28)$ \\
\hline $\mathbf{T}_{4}$ & 2.64 (1.90) & $4.92(2.42)$ & $9.81(3.28)$ & $8.26(3.04)$ & $3.98(2.23)$ & $1.09(1.44)$ \\
\hline $\mathbf{T}_{5}$ & $2.24(1.80)$ & $4.55(2.35)$ & $9.94(3.30)$ & $7.91(2.98)$ & $4.43(2.32)$ & $0.99(1.41)$ \\
\hline $\mathrm{T}_{6}$ & $2.34(1.82)$ & $4.22(2.28)$ & $9.71(3.27)$ & $8.16(3.02)$ & $3.65(2.15)$ & $1.17(1.47)$ \\
\hline $\mathbf{T}_{7}$ & $2.52(1.87)$ & $4.15(2.27)$ & $9.97(3.31)$ & $8.59(3.09)$ & $4.03(2.24)$ & $0.92(1.38)$ \\
\hline $\mathrm{T}_{8}$ & $2.78(1.94)$ & $4.37(2.31)$ & $9.34(3.21)$ & $8.15(3.02)$ & $3.95(2.22)$ & $0.55(1.23)$ \\
\hline$T_{9}$ & $2.66(1.91)$ & $3.83(2.19)$ & $9.46(3.23)$ & $7.77(2.96)$ & $4.25(2.29)$ & $0.85(1.34)$ \\
\hline $\mathbf{T}_{10}$ & $2.26(1.80)$ & $3.40(2.09)$ & $8.12(3.02)$ & $7.11(2.84)$ & $2.95(1.98)$ & $0.33(1.15)$ \\
\hline $\mathrm{SE} \mathrm{m} \pm$ & 0.06 & 0.07 & 0.06 & 0.05 & 0.05 & 0.07 \\
\hline $\mathrm{CD}(\mathrm{P}=0.05)$ & 0.18 & 0.23 & 0.18 & 0.15 & 0.16 & 0.20 \\
\hline CV (\%) & 5.65 & 5.69 & 3.34 & 2.94 & 4.42 & 8.72 \\
\hline
\end{tabular}

\begin{tabular}{|c|c|}
\hline $\begin{array}{l}\mathrm{T}_{1}: 75 \% \mathrm{RDF}+25 \% \text { RDN through composted coir } \\
\text { pith }\end{array}$ & $\begin{array}{l}\mathrm{T}_{2}: 75 \% \text { RDF }+25 \% \text { RDN through composted coir pith+50g Azospirillum }+50 \mathrm{~g} \\
\text { PSB }\end{array}$ \\
\hline $\begin{array}{l}\mathrm{T}_{3}: \mathbf{5 0} \% \mathrm{RDF}+\mathbf{5 0} \% \mathrm{RDN} \text { through composted coir } \\
\text { pith }\end{array}$ & $\mathrm{T}_{4}: 50 \% \mathrm{RDF}+50 \% \mathrm{RDN}$ through composted coir pith+50g Azospirillum + 50g PSB \\
\hline $\mathrm{T}_{5}: 75 \% \mathrm{RDF}+25 \% \mathrm{RDN}$ through FYM & $\mathrm{T}_{6}: 75 \% \mathrm{RDF}+25 \% \mathrm{RDN}$ through FYM+ 50g Azospirillum $+50 \mathrm{~g}$ PSB \\
\hline $\mathrm{T}_{7}: 50 \% \mathrm{RDF}+\mathbf{5 0 \%} \mathrm{RDN}$ through FYM & $\mathrm{T}_{8}: 50 \% \mathrm{RDF}+50 \% \mathrm{RDN}$ through FYM+ 50g Azospirillum + 50g PSB \\
\hline $\mathrm{T}_{9}: 100 \% \mathrm{RDF}$ & $\mathrm{T}_{10}:$ Control \\
\hline RDF- Recommended dose of fertilizers & RDN-Recommended dose of nutrients \\
\hline FYM- Farm yard manure & PSB-Phosphate solubilizing bacteria \\
\hline
\end{tabular}


Table.3 Effect of different INM treatments on flowers per cushion on fan branches of cocoa (Theobroma cacao L.)

\begin{tabular}{|c|c|c|c|c|c|c|}
\hline \multirow[t]{2}{*}{ Treatments } & \multicolumn{6}{|c|}{ Number of flowers/cushion in the fan branches } \\
\hline & July & August & September & October & November & December \\
\hline$T_{1}$ & $1.52(1.58)$ & $2.32(1.82)$ & $4.83(2.41)$ & $4.68(2.38)$ & $3.30(2.07)$ & 0.38 (1.17) \\
\hline $\mathbf{T}_{2}$ & $2.01(1.73)$ & $2.41(1.84)$ & $4.81(2.41)$ & 4.75 (2.39) & $3.55(2.13)$ & $1.23(1.49)$ \\
\hline $\mathrm{T}_{3}$ & $1.43(1.55)$ & $2.29(1.81)$ & $4.79(2.40)$ & $4.44(2.33)$ & $3.23(2.05)$ & $0.46(1.20)$ \\
\hline$\overline{T_{4}}$ & $1.36(1.53)$ & $2.24(1.80)$ & $4.93(2.43)$ & $4.66(2.37)$ & $4.35(2.31)$ & $0.31(1.14)$ \\
\hline$\overline{T_{5}}$ & $1.12(1.45)$ & $2.27(1.81)$ & $4.77(2.40)$ & $4.36(2.31)$ & $3.34(2.08)$ & $0.55(1.24)$ \\
\hline $\mathrm{T}_{6}$ & $1.14(1.46)$ & $2.17(1.78)$ & $4.81(2.41)$ & $4.47(2.33)$ & $3.77(2.18)$ & $0.22(1.10)$ \\
\hline$\overline{\mathbf{T}_{7}}$ & $1.23(1.49)$ & $2.21(1.79)$ & $4.75(2.39)$ & $4.61(2.36)$ & $2.94(1.98)$ & $0.35(1.16)$ \\
\hline$\overline{T_{8}}$ & $1.50(1.57)$ & $2.18(1.78)$ & $4.44(2.33)$ & $4.34(2.31)$ & $3.34(2.08)$ & $0.74(1.31)$ \\
\hline$T_{9}$ & $1.40(1.55)$ & $2.02(1.73)$ & $4.22(2.28)$ & $4.10(2.25)$ & $3.60(2.14)$ & $0.48(1.21)$ \\
\hline $\mathbf{T}_{10}$ & $1.16(1.46)$ & $1.58(1.60)$ & $3.85(2.20)$ & $3.30(2.07)$ & $2.32(1.82)$ & $0.25(1.12)$ \\
\hline SE $\mathbf{m} \pm$ & 0.05 & 0.03 & 0.04 & 0.04 & 0.04 & 0.05 \\
\hline $\mathrm{CD}(\mathrm{P}=0.05)$ & 0.15 & 0.10 & 0.12 & 0.13 & 0.13 & 0.17 \\
\hline CV (\%) & 5.61 & 3.54 & 3.09 & 3.35 & 3.74 & 8.33 \\
\hline
\end{tabular}

\begin{tabular}{|c|c|c|}
\hline $\begin{array}{l}\mathrm{T}_{1}: 75 \% \mathrm{RDF}+25 \% \text { RDN through composted coir } \\
\text { pith }\end{array}$ & \multicolumn{2}{|c|}{$\begin{array}{l}\mathrm{T}_{2}: 75 \% \text { RDF }+25 \% \text { RDN through composted coir pith+50g Azospirillum }+50 \mathrm{~g} \\
\text { PSB }\end{array}$} \\
\hline $\begin{array}{l}\mathrm{T}_{3}: \mathbf{5 0} \% \mathrm{RDF}+\mathbf{5 0} \% \mathrm{RDN} \text { through composted coir } \\
\text { pith }\end{array}$ & \multicolumn{2}{|c|}{$\mathrm{T}_{4}: 50 \% \mathrm{RDF}+50 \%$ RDN through composted coir pith+50g Azospirillum $+50 \mathrm{~g}$ PSB } \\
\hline $\mathrm{T}_{5}: 75 \% \mathrm{RDF}+25 \% \mathrm{RDN}$ through FYM & \multicolumn{2}{|c|}{$\mathrm{T}_{6}: 75 \% \mathrm{RDF}+25 \% \mathrm{RDN}$ through FYM+50g Azospirillum $+50 \mathrm{~g}$ PSB } \\
\hline $\mathrm{T}_{7}: 50 \% \mathrm{RDF}+50 \% \mathrm{RDN}$ through FYM & \multicolumn{2}{|c|}{$\mathrm{T}_{8}: 50 \% \mathrm{RDF}+50 \% \mathrm{RDN}$ through FYM+50g Azospirillum + 50g PSB } \\
\hline $\mathrm{T}_{9}: 100 \% \mathrm{RDF}$ & \multicolumn{2}{|c|}{$\mathrm{T}_{10}:$ Control } \\
\hline RDF- Recommended dose of fertilizers & RDN-Recommended dose of nutrients & FYM- Farm yard manure \\
\hline PSB-Phosphate solubilizing bacteria & CCP- Composted coir pith & \\
\hline
\end{tabular}


Table.4 Effect of different INM treatments on total number of flowers per tree and pod setting percent of cocoa (Theobroma cacao L.)

\begin{tabular}{|c|c|c|c|c|c|c|c|}
\hline Treatments & $\begin{array}{l}\text { Total number } \\
\text { of flowers/ } \\
\text { main stem/tree }\end{array}$ & $\begin{array}{l}\text { Total number of } \\
\text { flowers/ } \\
\text { fan branches / tree }\end{array}$ & $\begin{array}{l}\text { Total number of } \\
\text { flowers /tree }\end{array}$ & $\begin{array}{c}\text { Total number } \\
\text { of cherelles } \\
\text { /tree }\end{array}$ & $\begin{array}{c}\text { Total } \\
\text { healthy } \\
\text { pods } \\
\text { harvested }\end{array}$ & $\begin{array}{c}\text { Total } \\
\text { damaged } \\
\text { pods } \\
\text { harvested }\end{array}$ & $\begin{array}{l}\text { Pod setting } \\
(\%)\end{array}$ \\
\hline$T_{1}$ & $971.54(31.15)$ & $2704.81(51.76)$ & $3676.36(60.43)$ & $92.24(9.64)$ & 51.43 & 0.78 & $4.07(11.56)$ \\
\hline$\overline{T_{2}}$ & $1256.35(35.39)$ & $3577.50(59.80)$ & $4833.85(69.53)$ & $152.65(12.36)$ & 55.84 & 0.37 & 4.32 (11.98) \\
\hline$T_{3}$ & $939.82(30.61)$ & $2944.41(54.16)$ & $3884.23(62.29)$ & $74.24(8.65)$ & 43.33 & 0.97 & 3.07 (10.07) \\
\hline $\mathbf{T}_{4}$ & 926.45 (30.32) & 3014.64 (54.79) & 3941.09 (62.24) & $62.23(7.94)$ & 44.54 & 0.59 & $2.80(9.58)$ \\
\hline$\overline{T_{5}}$ & $951.98(30.85)$ & $2860.09(53.43)$ & 3812.07 (61.69) & $71.29(8.50)$ & 43.59 & 0.44 & $3.04(10.03)$ \\
\hline $\mathrm{T}_{6}$ & 967.32 (31.09) & $2724.31(52.08)$ & $3691.63(60.65)$ & $78.21(8.88)$ & 45.58 & 0.49 & $3.40(10.61)$ \\
\hline $\mathbf{T}_{7}$ & $1040.63(32.23)$ & $2842.45(53.23)$ & $3883.08(62.23)$ & $64.26(8.07)$ & 44.49 & 0.44 & $2.86(9.70)$ \\
\hline $\mathrm{T}_{8}$ & $962.43(31.02)$ & $2556.53(50.40)$ & $3518.96(59.20)$ & $61.28(7.88)$ & 43.17 & 0.93 & $3.03(10.01)$ \\
\hline$T_{9}$ & $1040.44(32.17)$ & $2534.14(50.07)$ & $3574.58(59.54)$ & $59.89(7.80)$ & 40.65 & 0.74 & $2.94(9.82)$ \\
\hline $\mathbf{T}_{10}$ & $600.52(24.49)$ & $1418.97(37.64)$ & $2019.50(44.89)$ & $10.13(3.33)$ & 26.03 & 1.21 & $1.86(7.81)$ \\
\hline $\mathrm{SE} \mathbf{m} \pm$ & 1.05 & 2.38 & 2.29 & 0.32 & 1.06 & 0.05 & 0.50 \\
\hline $\mathrm{CD}(\mathrm{P}=0.05)$ & 3.15 & 7.14 & 6.87 & 0.96 & 3.17 & 0.15 & 1.50 \\
\hline CV $(\%)$ & 5.89 & 7.99 & 6.59 & 6.68 & 4.18 & 12.61 & 8.61 \\
\hline
\end{tabular}

$\mathrm{T}_{1}: \mathbf{7 5} \% \mathrm{RDF}+\mathbf{2 5} \% \mathrm{RDN}$ through composted coir pith

$\mathrm{T}_{3}: 50 \%$ RDF $+50 \%$ RDN through composted coir pith

$\mathrm{T}_{5}: 75 \% \mathrm{RDF}+25 \% \mathrm{RDN}$ through FYM

$\mathrm{T}_{7}: 50 \% \mathrm{RDF}+\mathbf{5 0 \%} \mathrm{RDN}$ through FYM

$\mathrm{T}_{9}: 100 \% \mathrm{RDF}$

RDF- Recommended dose of fertilizers

FYM- Farm yard manure

Figures in parenthesis indicates square root and arc sine transform PSB
$\mathrm{T}_{2}: \mathbf{7 5} \% \mathrm{RDF}+25 \% \mathrm{RDN}$ through composted coir pith+50g Azospirillum + 50g

$\mathrm{T}_{4}: 50 \% \mathrm{RDF}+50 \% \mathrm{RDN}$ through composted coir pith+50g Azospirillum $+50 \mathrm{~g}$ PSB $\mathrm{T}_{6}: 75 \% \mathrm{RDF}+25 \% \mathrm{RDN}$ through FYM+ 50g Azospirillum + 50g PSB

$\mathrm{T}_{8}: 50 \% \mathrm{RDF}+50 \% \mathrm{RDN}$ through FYM+ 50g Azospirillum + 50g PSB

$\mathrm{T}_{10}$ : Control

RDN-Recommended dose of nutrients CCP-Composted coir pith

PSB-Phosphate solubilizing bacteria 
Among the flower characters, flower cushions per tree and number of flowers per cushion are considered as the important trait for consideration of yield in cocoa. The flower cushions in cocoa are spread over the trunk and main branches, the number is influenced more due to the soil nutrient, climatic conditions existed in the previous year. Better photo-assimilates and hormonal balance would have improved the sink strength of trees treated with cent \% RDF through acceleration of mega and microsporogenesis and differentiation of axillary buds into reproductive ones.

It was found that higher level of $\mathrm{N}, \mathrm{P}$ and $\mathrm{K}$ resulted in increased area of the pollen grain. High level of auxin-like substances may promote flowering parameters either by nullifying the effect of GA3 (or) by decreasing the permeability of cell membrane, particularly the plasmalemma. The results were also reported by Krishnamoorthy et al., 2015. The highest flower cushions and flower per cushions was reported in $\mathrm{T}_{2}(75 \% \mathrm{RDF}+$ $25 \% \mathrm{RDN}$ through $\mathrm{CCP}+50 \mathrm{~g}$ Azospirillum $+50 \mathrm{~g}$ PSB).

This might be attributed to improved nutrient use efficiency with the balanced use of organic and inorganic source of nutrients. Application of composted coir pith with NPK fertilizer improved the soil texture and porosity due to bulkiness in nature, which may helped the plant root development and enhance the uptake of available nutrients resulting into faster cell division and cell elongation; consequently increase the flowering in the plants. The Azospirillum in fixation of atmospheric nitrogen and PSB involve in solubulisation of phosphate in soil are responsible to compensate the half dose of NPK and maintain the soil environment which ultimately reflect on the flowering of tree. The results were also reported with Yadav et al., (2011). In cocoa, pod set per cent was very low during dry season. Pod set was observed to be low in April but gradually increased till it reaches the peak in September. In addition to this, the pollinators which are moisture-loving dipterans, might be much less in number during the dry seasons thus lead to poor pod set per cent in cocoa. The similar results were also in line the findings of Falque et al., (1993) in cocoa. Takahashi et al., (1993) also found that higher level of $\mathrm{N}, \mathrm{P}$ and $\mathrm{K}$ resulted in increased area of the pollen grain. High pollen output, increased pollen germination are the main factors contributing to increase the pod set. These findings were also reported by Murali and suresh (2015).

The highest pod set percent was recorded in $T_{2}$ followed by $T_{1}$. The better vegetative growth due to organics might have reflected in increased production of flowers and resulted in higher per cent fruit set. By increased fruit set due to composted coir pith could be attributed to the presence of plant hormones and chemical exudates released during biological activity promoted by the coir pith in the soil. Composted coir pith has very high porosity, aeration, drainage and water holding capacity and has a vast surface area, providing strong absorbability and retention of nutrients for longer period of time hence maximizing fruit setting percentage. Naik and HariBabu (2007), Singh et al., (2008) and Dhomane et al., (2011) in guava also reported similar results.

\section{Acknowledgement}

The authors are thankful to financial support rendered by Dr. Y.S.R Horticultural University and Horticultural Research station, Ambajipeta for providing field during the course of post-graduation education. We are equally grateful to staff members of HRS, Ambajipeta for technical support and providing fertilizers used for the study. 


\section{References}

Alversson, W.S., Whitlock, B.A., Nyffeler, R., Bayer, C. and Baum, D.A. 1999. Phylogeny of the core Malvales: evidence from Ndhf sequence data. American Journal of Botany. 86(10): 1474-1486.

Bayer, C., Fay, M.F., De Bruijn, A.Y., Savolainen, V., Morton, C.M., Kubitzki, K., Alverson, W.S. and Chase, M.W. 1999. Support for an expanded family concept of Malvaceae within a recircumscribed order Malvales: a combined analysis of plastid atpB and rbcL DNA sequences. Botanical Journal of the Linnean Society.129: 267-303.

Dhomane, P.A, Kadam, A.S, Lakade, S.K. and Gharage, V.R. 2011. Effect of different sources of nitrogen on growth and yield of guava (Psidium guajava L.) cv. Sardar. Asian journal of Horticulture. 6(1): 92-95.

Falque, M, Vincent, A. and Beaucamp, J. 1993. Relation between amount of pollen deposited on the styles and pod set in Theobroma cacao L. In: Proceedings of the 11th International Cocoa Research Conference, Book of Summaries. Yamoussoukro, Cote dIvoire. pp. 18-24.

Krishnamoorthy, C and Rajamani, K. 2013. Effect of Fertigation through Drip and Micro Sprinkler on Plant Biometric Characters in Cocoa (Theobroma cacao L.). Pakistan Journal of Biological Science. 16: 1950-1956.
Motamayor, J.C., Risterucci, A.M., Lopez, P.A, Ortiz, C.F., Moreno, A. and Lanaud, C. 2002. Cacao domestication I: the origin of the cacao cultivated by the Mayas. Heredity. 89: 380-386.

Murali.K. and Suresh. J. 2015. Evaluation of different Cocoa Clones under different ecological condition of Tamil Nadu for Flowering, Pod Set and Yield. Journal of Environmental Sciences. 7: 95-100.

Naik, M.H. and HariBabu, R. 2007. Feasibility of Organic Farming in Guava (Psidium guajava L.). Acta Horticulturae. 735: 365-372.

Singh, V, Dashora, L.K, Karatha, K.M, Ahalawat, T.R. and Barad, A.V. 2008. Growth, flowering, fruiting and yield of guava (Psidium guajava L.) cv. 'SARDAR' grown under high-densityplanting system as influenced by various organic and inorganic sources. Asian Journal of Horticulture. 3(2): 382-385.

Takahashi, H, Shennan, C and Huffaker, R.C. 1993. Agronomical and physiological studies on zinc deficiency in crop plants. Nettai Nogyo. 37 (1): 22-27.

Thondaiman, V. 2011. Studies on genetic diversity and molecular characterization of cocoa (Theobroma cacao L.). Scientific Publication. Pp. 71-76.

Yadav, A.K., Singh, J.K and Singh, H.K. 2011.Studies on integrated nutrient management in flowering, fruiting, yield and quality of mango cv. Amrapali under high density orcharding. Indian Journal of Horticulture. 68(4): 453-460

\section{How to cite this article:}

Leela Janaki, P., G. Ramanandam and Sasikala, K. 2018. Effect of Integrated Nutrient Management on Flowering Characters of Cocoa. Int.J.Curr.Microbiol.App.Sci. 7(01): 13481356. doi: https://doi.org/10.20546/ijcmas.2018.701.164 